\title{
Monitoring the efficacy of intraarticular infliximab by musculoskeletal ultrasound and juvenile arthritis disease acitivty score (JADAS) in JIA patients - single center experience
}

\author{
Mandica Vidovic ${ }^{1 *}$, Lovro Lamot ${ }^{1,2}$, Marija Perica', Lana Tambic Bukovac ${ }^{1}$, Miroslav Harjacek ${ }^{1}$ \\ From 21st European Pediatric Rheumatology (PReS) Congress \\ Belgrade, Serbia. 17-21 September 2014
}

\section{Introduction}

Pediatric rheumatologists use musculoskeletal ultrasound (MSUS) in everyday practice as a simple, painless and inexpensive tool for detecting synovitis. Along with MSUS, Juvenile Arthritis Disease Activity Score (JADAS) was proven to be valid for clinical assessment. In JIA patients with mono- or oligoarthritis who are inadequately responding to conventional therapy, but do not meet criteria for biological therapy, intraarticular infliximab could be therapy of choice. Since this therapeutic option is not routinely used, there is a need for a continuous follow-up, in which MSUS and JADAS could have great value.

\section{Objectives}

To assess the efficacy of intraarticular infliximab injections in patients with juvenile idiopathic arthritis (JIA) using MSUS and juvenile arthritis disease activity score (JADAS).

\section{Methods}

IA infliximab was administered in 22 joints of 14 patients diagnosed with JIA according to ILAR classification criteria. All patients received first and second line therapy (NSAID, DMARD, corticosteroids systemic and IA). None of the patients fulfilled criteria for treatment with biologic therapeutics, but were resistant to DMARD's. Intraarticular infliximab $(25 \mathrm{mg}$ or $50 \mathrm{mg}$ per joint) was administered.

${ }^{1}$ Pediatric and Adolescent Rheumatology, Children's Hospital Srebrnjak Croatia

Full list of author information is available at the end of the article
The patients were monitored by monthly assessment using JADAS (number of active joints, pain assessed by patient/parent an physician (VAS), ESR) and MSUS. The MSUS assessment included Omeract semiquantitative grades (0-3 grades) for both B-mode and PowerDoppler (PD) and 12 patients were examined using 3D/ 4D US. We used paired samples T-test for comparing JADAS before and after the treatment.

\section{Results}

At the point of IA injections all 22 joints showed grade 2-3 synovitis in B mode and increased PD signal (2-3/3). The mean value of JADAS was $17.31( \pm 2.78)$. At the end of the follow-up period (mean time 7.07 months, range 6-10 months) the mean value of JADAS was $5.66( \pm 3.52)$. There was also improvement in MSUS with 0-1 grade synovitis without effusion in $B$ mode and PD signal decreased to $0-1 / 3$. The deference in JADAS was statistically significant $(\mathrm{p}<0.001)$. However, $3 / 14$ patients subsequently flared (mean time 6-8 months) and fulfilled criteria for systemic biologic therapy. Two of those three patients received lower IA dose of infliximab (25 mg per joint).

\section{Conclusion}

IA infliximab should still be considered as a therapy option in selected children with therapy resistant, isolated mono/oligoarticular JIA. The effect of IA therapy could be easily monitored both by MSUS and JADAS.

\section{Disclosure of interest}

None declared. 


\section{Authors' details}

'Pediatric and Adolescent Rheumatology, Children's Hospital Srebrnjak .

Croatia. ${ }^{2}$ University of Zagreb School of Medicine, zagreb, Croatia.

Published: 17 September 2014

\section{doi:10.1186/1546-0096-12-S1-P22}

Cite this article as: Vidovic et al:: Monitoring the efficacy of intraarticular infliximab by musculoskeletal ultrasound and juvenile arthritis disease acitivty score (JADAS) in JIA patients - single center experience.

Pediatric Rheumatology 2014 12(Suppl 1):P22.

Submit your next manuscript to BioMed Central and take full advantage of:

- Convenient online submission

- Thorough peer review

- No space constraints or color figure charges

- Immediate publication on acceptance

- Inclusion in PubMed, CAS, Scopus and Google Scholar

- Research which is freely available for redistribution

Submit your manuscript at www.biomedcentral.com/submit
Ciomed Central 